\title{
新しい非カフ型カテーテルの脱血不良改善効果の検討
}

\author{
瀧 本さち ${\text { 開 正 宏 }{ }^{1} \text { 石川 英昭 }{ }^{2} \text { 市田 静 憲 }}^{3}$ \\ 1名古屋第一赤十字病院臨床工学技術課 2 名古屋第一赤十字病院腎臟内科 \\ 3リブラささしまメディカルクリニック
}

キーワード：非カフ型カテーテル，脱血不良

〈要旨〉

新たな非力フ型カテーテルの導入を機に, 脱血不良の頻度および留置成績を従来品と比較した. 2015 年 1 月から 2016 年 2 月までに使用されたカテーテル 148 本を対象に, 脱血不良の発生頻度を後乃向きに検討した. 脱血不良発 生をカテーテルの逆接続実施と定義し, 従来品を A 群, 新規導入品を B 群とした. 患者背景のうち留置部位では A 群で内頸静脈留置が有意に多かった $(p=0.004)$. 脱血不良は全体で $29.7 \%$ 発生しており, 群間別では $A$ 群 $37.6 \%$, $B$ 群 $19.0 \%$ と B 群で有意に低く $(p=0.014)$, 留置部位別では大腿静脈留置において B 群で有意に脱血不良が少な かった $(p=0.005)$. 留置期間に有意差は認めず $(p=0.904)$, トラブルによるカテーテル交換は $\mathrm{B}$ 群で有意に少な かった $(p=0.024)$. 新規導入したカテーテルは従来品に比し有意に脱血不良が少なく, 特に大腿静脈留置時におい て有効であることが示唆された。

\section{Usefulness of new non-cuffed catheters for improving blood flow}

\author{
Sachi Takimoto ${ }^{1}$, Masahiro Hiraki ${ }^{1}$, Hideaki Ishikawa ${ }^{2}$, Shizunori Ichida ${ }^{3}$ \\ ${ }^{1}$ Department of Clinical Engineering, Japanese Red Cross Nagoya Daiichi Hospital \\ ${ }^{2}$ Division of Nephrology, Japanese Red Cross Nagoya Daiichi Hospital \\ ${ }^{3}$ LIBRA Sasashima Medical Clinic
}

Keywords: non-cuffed catheters, insufficient blood flow

〈Abstract〉

Due to the introduction of new non-cuffed catheters, we performed a comparative study examining the frequency of insufficient blood flow and the indwelling duration between patients that were treated with conventional catheters and those that were treated with the new catheters. We retrospectively studied the frequency of insufficient blood flow in patients that received catheter treatment between January 2015 and February 2016, in whom 148 catheters were used. Insufficient blood flow was defined as when the catheter connection had to be reversed. We defined the patients treated with conventional catheters as group $A$, and the remaining patients as group $B$. As for the backgrounds of the two groups, the frequency of internal jugular vein placement was significantly higher in group A than in group B $(p=0.004)$. Insufficient blood flow occurred in $29.7 \%$ of all 148 catheters and was significantly less common in group B $(19.0 \%)$ than in group A $(37.6 \%)(p=0.014)$. Insufficient blood flow was also significantly less common in group $B$ than in group $A$ after femoral vein placement $(p=0.005)$. There were no significant intergroup differences in the indwelling period $(p=0.904)$, but catheter changes due to various problems were significantly less common in group $\mathrm{B}(p=0.024)$. The new catheters significantly reduced the frequency of insufficient blood flow. In addition, the new catheters were suggested to be especially useful for femoral vein placement.

瀧本 さち 名古屋第一赤十字病院臨床工学技術課 ～４53-8511 愛知県名古屋市中村区道下町 3-35

Sachi Takimoto Tel: 052-481-5111 Fax：052-482-7733

〔受付日：2018 年 3 月 7 日, 受理日：2018 年 9 月 6 日〕 


\begin{tabular}{lccc}
\hline & 外径 & カテーテル長 & 㨂入部位 \\
\hline ブラッドアクセスUKカテーテル & $12 \mathrm{Fr}$. & $15 \mathrm{~cm}$ & 内頸静脈 \\
ブラッドアクセスUKカテーテル & $12 \mathrm{Fr}$. & $25 \mathrm{~cm}$ & 大腿静脈 \\
パワートリアライシス & $13 \mathrm{Fr}$. & $15 \mathrm{~cm}$ & 内頸静脈 \\
パワートリアライシス & $13 \mathrm{Fr}$. & $24 \mathrm{~cm}$ & 大腿静脈 \\
\hline
\end{tabular}

\section{緒 言}

非カフ型カテーテル (以下 non-cuffed カテーテル : NC カテーテルとする) は, 持続的血液濾過透析（continuous hemodiafiltration：CHDF）を含めたアフェレ シス療法や, 透析の緊急導入時, または維持透析患者 のシャントトラブルに対するバスキュラーアクセスと して使用されている。当院は外来透析を行っておら ず，入院患者に対して透析導入やさまざまな血液浄化 を施行している。 また，三次救急病院であり，昇圧薬 が必要で重篤な心血管疾患を有する患者のための薬剤 ルート, 中心静脈栄養のためのルートとして輸液ルー メンを備えたトリプルルーメンカテーテルを全症例使 用している. NCカテーテル使用時の問題点としては, 脱血不良やカテーテル感染等があげられる ${ }^{11}$ 。脱血不 良が発生すると, 正常時に比して十分な血流量が得ら れず，透析効率が低下し治療の妨げとなる．脱血不良 発生時の対処としては, 血流量を下げる・NCカテー テル固定部分での位置調整を行う・回路の脱血側と返 血側を逆接続するなどがあげられ，血流量を確保でき るような対処が必要となる ${ }^{2)}$. しかし, 脱血不良が頻 回に起こり対処しても改善されない場合, 血液滞留に よって凝血がおこり，膜や回路の交換が必要となるだ けでなく， NCカテーテルの交換も必要となることが ある. 脱血不良の対処方法の一つである逆接続は, 再 循環率を増加させるため, 順接続ほどの透析効率は得 られない吕) と報告されているが，当院では NC カテー テル交換に至る前の最終手段として行っている．今 回，われわれは新たな NC カテーテルの導入を機に， 脱血不良の発生頻度および NC カテーテルの留置成績 について NC カテーテルによる違いを検討したので報 告する。

\section{I. 方 法}

\section{1. 対象と期間}

2015 年 1 月から 2016 年 2 月までに使用された NC カテーテル 148 本を対象に後ろ向きに検討を行った. 対象期間中に用いた NC カテーテルは 2 種類でいずれ
もトリプルルーメンのエンドホールタイプカテーテル であり,ブラッドアクセス UK-カテーテル（製造販売 元：ニプロ株式会社）を $\mathrm{A}$ 群，パワートリアライシス （製造販売元：株式会社メディコン）を B 群とした. 対象となった NCカテーテル本数はそれぞれ，A 群 85 本，B群 63 本だった。使用した $\mathrm{NC}$ カテーテルは表 1 のとおりである。

\section{2. 脱血不良の定義}

脱血不良の対処方法として当院では， NC カテーテ ルの先端位置を変える方法（NCカテーテルを引き抜 く, 挿入部に沈子を当てて $\mathrm{NC}$ カテーテルの先端角度 を変えるなど)，または生理食塩水でフラッシュを行 う方法や血液ポンプの設定流量調節（その時点で得る ことのできる最大血流量に合わせて設定血流量を下げ る方法）等を適宜行っている. 当院では逆接続実施が $\mathrm{NC}$ カテーテル交換前に行う最終手段として位置づけ ており，逆接続を行った際には実施記録を残すことに している。 そのため, 本研究では逆接続の実施を脱血 不良発生として定義した。

\section{3. 分析方法}

$\mathrm{NC}$ カテーテルによる脱血不良の発生頻度を比較し た。さらに，留置期間と交換理由についても両群間で の差異を検討した． 統計解析には $\chi^{2}$ 検定および student の $\mathrm{t}$ 検定を用い, $p<0.05$ を統計学的有意差あり とした。

\section{4. 倫理的配慮}

本研究は名古屋第一赤十字病院倫理委員会の承認 （承認番号：2018-033）を得て行った.

\section{II. 結 果}

\section{1. 患者背景}

研究対象となった NC カテーテル 148 本が留置され た患者は 92 名で，男性 60 名 (95 本)，女性 32 名（53 本）であった．各群における患者背景を表 2 に示す. 両群間において性別による有意差はみられなかった。 患者の留置部位において両群間で有意差がみられ, 内 頸静脈留置および右側への留置がともに $\mathrm{A}$ 群で有意 に多かった．留置部位の内訳としては，A 群では右内 頸静脈留置が 39 本 $(45.9 \%)$ ， B 群で右大腿静脈留置 
表 2 患者背景

\begin{tabular}{lccc}
\hline & $\mathrm{A}$ 群 & $\mathrm{B}$ 群 & \multirow{2}{*}{$\mathrm{N}$ 值 } \\
& $\mathrm{N}=85$ & $\mathrm{~N}=63$ & \\
\hline 性別(男性) & $55(64.7 \%)$ & $40(63.5 \%)$ & 0.879 \\
留置部位 (内頸) & $44(51.8 \%)$ & $17(27.0 \%)$ & 0.004 \\
留置部位 (右) & $68(80.0 \%)$ & $41(65.1 \%)$ & 0.042 \\
急性血液浄化 & $52(61.2 \%)$ & $37(58.7 \%)$ & 0.764 \\
$\mathrm{CHDF}$ 施行 (長時間) & $19(22.4 \%)$ & $13(20.6 \%)$ & 0.802 \\
\hline
\end{tabular}

表 3 留置部位の内訳

\begin{tabular}{lrr}
\hline & $\mathrm{A}$ 群 & \multicolumn{1}{c}{$\mathrm{B}$ 群 } \\
& $\mathrm{N}=85$ & $\mathrm{~N}=63$ \\
\hline 内頸 右 & $39(45.9 \%)$ & $15(23.8 \%)$ \\
内頸 左 & $5(5.9 \%)$ & $2(3.2 \%)$ \\
大腿 右 & $29(34.1 \%)$ & $26(41.3 \%)$ \\
大腿 左 & $12(14.1 \%)$ & $20(31.7 \%)$ \\
\hline
\end{tabular}

表 4 脱血不良

\begin{tabular}{lllll}
\hline & $\mathrm{N}$ & $\begin{array}{c}\text { 脱血不良あり } \\
\text { 度数 }(\%)\end{array}$ & $\begin{array}{c}\text { 脱血不良なし } \\
\text { 度数 }(\%)\end{array}$ & $p$ 值 \\
\hline $\mathrm{A}$ 群 & 85 & $32(37.6 \%)$ & $53(62.4 \%)$ & 0.014 \\
B 群 & 63 & $12(19.0 \%)$ & $51(81.0 \%)$ & 0.04 \\
\hdashline 全体 148 & $44(29.7 \%)$ & $104(70.3 \%)$ & \\
\hline
\end{tabular}

が 26 本 (41.3\%) でそれぞれ最も多かった（表 3). 急 性血液浄化を施行した患者割合において有意差はみら れず，長時間施行するCHDF 患者の割合においても有 意差は認めなかった。

\section{2. 脱血不良の発生頻度}

脱血不良は，全体で 44 本 $(29.7 \%)$ 発生しており， 群間別に比較すると A 群 32 本 $(37.6 \%)$, B 群 12 本 (19.0\%) と有意にB 群で発生頻度が低かった（ $p=$ 0.014）（表 4）.

\section{3. 留置部位別の比較}

患者背景のうち, 両群間で差のみられた留置部位ご とに両群間の脱血不良の発生頻度を比較した。内頸静 脈留置群では両群間に有意差を認めなかったが，大腿 静脈留置群では B 群において有意に脱血不良が少な かった（ $p=0.005 ）$ (表 5).

\section{NC カテーテル留置成績}

留置期間は, A 群 $9.5 \pm 0.77$ 日, B 群 $9.4 \pm 0.92$ 日で 両群間に有意差はみられなかった $(p=0.904)$. 何らか のトラブルによる NCカテーテルの交換は全体で 14 本 (9.5\%) 発生しており, A 群 12 本 $(14.1 \%)$, B 群 2 本 $(3.2 \%)$ と B 群で有意に少なかった $(p=0.024)$. 交換 理由となったトラブルの内訳は表 6 に示すとおりであ る.
表 5 留置部位別

\begin{tabular}{|c|c|c|c|c|c|}
\hline & & $\mathrm{N}$ & 脱血不良あり & 脱血不良なし & $p$ 值 \\
\hline 内頸静脈 & $\begin{array}{l}\mathrm{A} \text { 群 } \\
\mathrm{B} \text { 群 }\end{array}$ & $\begin{array}{l}44 \\
17\end{array}$ & $\begin{array}{r}16(36.4 \%) \\
6(35.3 \%)\end{array}$ & $\begin{array}{l}28(63.6 \%) \\
11(64.7 \%)\end{array}$ & 0.938 \\
\hline 大腿静脈 & $\begin{array}{l}\mathrm{A} \text { 群 } \\
\mathrm{B} \text { 群 }\end{array}$ & $\begin{array}{l}41 \\
46\end{array}$ & $\begin{array}{r}16(39.0 \%) \\
6(13.0 \%)\end{array}$ & $\begin{array}{l}25(61.0 \%) \\
40(87.0 \%)\end{array}$ & 0.005 \\
\hline
\end{tabular}

表 6 トラブルによる非カフ型カテーテル交換

\begin{tabular}{lccc}
\hline & $\mathrm{A}$ 群 & $\mathrm{B}$ 群 & \multirow{2}{*}{$\mathrm{N}$ 值 } \\
& $\mathrm{N}=85$ & $\mathrm{~N}=63$ & \\
\hline トラブル なし & $73(85.9 \%)$ & $61(96.8 \%)$ & \multirow{2}{*}{0.024} \\
トラブル あり & $12(14.1 \%)$ & $2(3.2 \%)$ & \\
\hline (内訳) & & & \\
カテーテル感染 & $5(41.7 \%)$ & $1(50.0 \%)$ & \\
脱血不良 & $4(33.3 \%)$ & $1(50.0 \%)$ & \\
回路内凝血 & $2(16.7 \%)$ & $0(0.0 \%)$ & \\
$\quad$ 血栓 & $1(8.3 \%)$ & $0(0.0 \%)$ & \\
\hline
\end{tabular}

\section{III. 考 察}

NC カテーテルは，一定期間において血液浄化に必 要な血流量を得ることを目的として使用される。しか し，脱血不良が起こると治療効率に影響を及ぼすだけ でなく, 治療再開のために行う回路交換などがコスト 面に影響し, さらには医療事故やカテーテル感染をひ き起こす可能性があり重大なリスクを伴う.

脱血不良の要因としては, 主に血栓形成, NC力 テーテル先端でみられる血管壁のへばりつき, $\mathrm{NC} カ$ テーテルの折れ曲がりによる内腔面積の低下すなわち 内腔の閉塞などがあげられる 生に関与し状態も似ているため, 鑑別が難しい. 血栓 形成の予防としては, 治療終了時に行うへパリン充填 や非使用時の生理食塩水フラッシュなどが行われ，ま た NCカテーテルの構造においても, 先端形状や脱血 孔が進化してきた. へばりつきに対しては, 患者の体 動抑制, NC カテーテルの挿入固定位置や向き調整, 血流量調整など治療中の処置に加え, 血栓形成と同じ く NCカテーテルの先端形状や脱血孔に対して改良が なされてきた. また, 内腔の閉塞に対しては, 扱入部 位の過度な屈曲抑制, 適切な穿刺部位の選択などに加 えて, NC カテーテルの長さや素材・シャフトの構造 や形状が改良されている. 上記のように，脱血不良の 予防と対策としては, 治療に関連した対処とカテーテ ルの構造特性に大別される。本研究では群間別で脱血 不良の発生頻度が異なる結果が得られ, 両群とも治療 時には同様に処置したため, NC カテーテル構造の違 いが影響していると考えられる。 


\section{A 群}

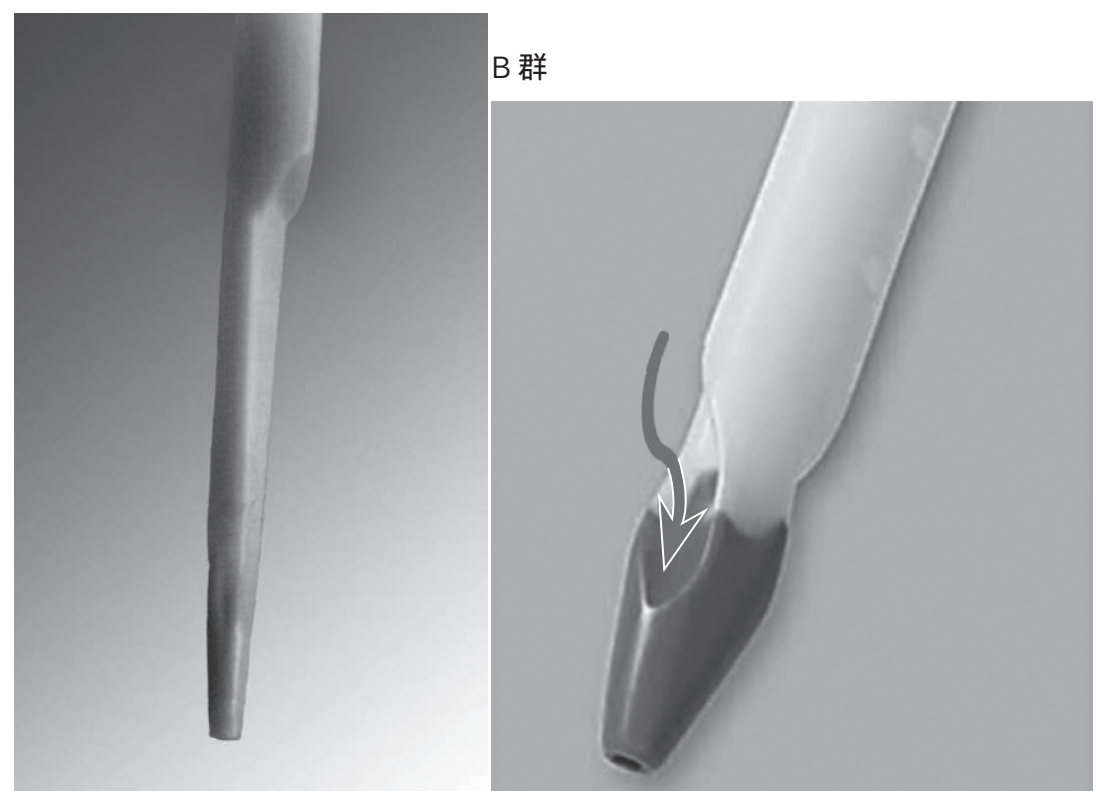

図 1 カテーテル先端の形状

(ニプロ株式会社, 株式会社メディコン両社より画像提供いただき, 筆者らで加筆)
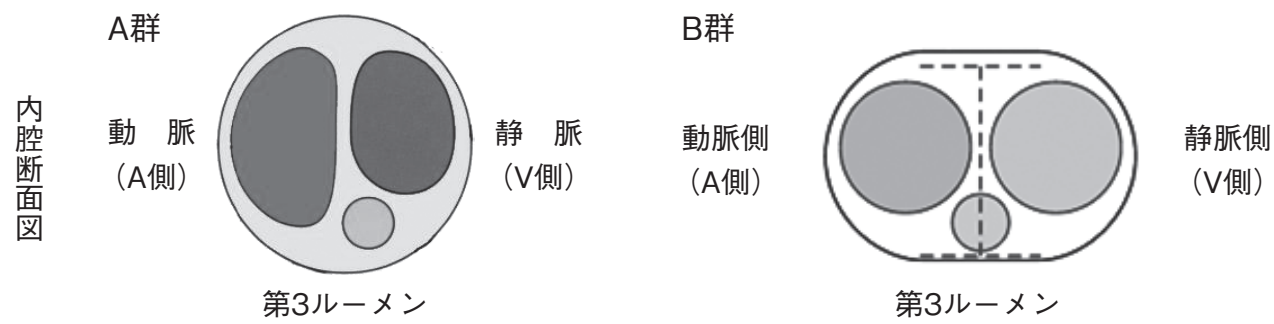

図 2 カテーテルの構造の違い

(ニプロ株式会社，株式会社メディコン両社より画像提供いただき，筆者らで加筆）

$\mathrm{NC}$ カテーテルの血栓形成やへばりつきに対して は, 先端構造の異なるエンドホール型がサイドホール 型より優れ，脱血不良がおこりにくいと報告されてい $ろ^{5 \sim 7)}$. さらにエンドホール型でも脱血孔の数や配置, または脱血孔から血管壁までの距離も影響するといわ れている ${ }^{8,9)}$. 本研究では, B 群において有意に脱血不 良が少なかった．A群に用いたカテーテルの構造は脱 血孔と送血孔の位置をずらしたエンドホール型の形状 をしており (図 1 左), サイドホールのみ有するカテー テルよりへばりつきに強い構造をしている. B 群のカ テーテルは, エンドホールとサイドホールの両方を併 せ持っている。エンドホールの形状はカテーテルシャ フトに沿って捻じれた楕円状のような立体流線形の脱 血孔・送血孔がそれぞれ半周ずつ対称に開き, サイド ホールは脱血側と送血側の両方にあり，非対称的な位 置に設けられている(図 1右)。これらの特徵を併せ持 つことにより血管壁のへばりつきが発生した際にも完 全に脱血孔が塞がれることなく, へばりつきが抑えら
れ血栓形成が起きにくかったと推測される.さらに， シャフトの断面が $\mathrm{A}$ 群のカテーテルでは円形であっ たため，どの方向に対しても折れ曲がり易かったが， B 群では楕円形であり, シャフト内腔に I 型の梁があ るような構造をしているため, 折れ曲がりに強く内腔 の閉塞が起きにくかったと考えられる（図 2).このよ うなカテーテルが持つ構造特性により, B 群の脱血不 良が少なかったことが示唆される.

また，挿入部位は内頸静脈のほうが大腿静脈より $\mathrm{NC}$ カテーテルの折れ曲がりが起きにくく, 脱血不良 になりにくいとされており,さらに NCカテーテルの 先端が上大静脈と右房の接合部付近にまっすぐ挿入で きる右内頸静脈からの挿入が，最も適しているといわ れている ${ }^{10,11)}$. 当院では ICU や救命救急センターなど で血液浄化を施行する患者は, 手術後や重症例が多 く, 中心静脈カテーテルやスワンガンツカテーテルの 留置に内頸静脈が使用されることがあるため, NC カ テーテルの留置部位として右内頸静脈が選択できない 
場合もある．既報でも手術後の透析施行時において， 循環動態のモニタリングや輸液・薬剤投与ラインに内 頸静脈が使用されているため, NC カテーテル留置部 位に大腿静脈の使用が多いと報告されており ${ }^{12)}$, 実際 の臨床場面では必ずしも留置部位の第一選択に内頸静 脈が使用できない場合もある，本研究では，有意に $\mathrm{A}$ 群で内頸静脈, 右側への留置が多かった，A 群では施 行中, 体動や体位変換・ベッドのギャッジアップ時に, $\mathrm{NC}$ カテーテルの折れ曲がりが原因と考えられる脱血 不良時の対応に苦慮していた。 B 群は使用開始時か ら, 従来品よりシャフトが柔らかく折れ曲がりに強い という印象を得ていたため, 大腿静脈留置などに多く 使用したことから群間での留置部位の偏りが生じたと 考えられる.

$\mathrm{B}$ 群では留置部位として大腿静脈や左側への留置が 多かったにもかかわらず，脱血不良が少なかった。こ のような結果が得られたのは, 新しい NC カテーテル の形状特性による折れ曲がりに対する強さが優れてい たためではないかと考える。また, Mayaらの報告で は, 大腿静脈留置でのカテーテル交換原因の $71 \%$ が脱 血不良であり，血栓形成や座位によるカテーテル屈曲 が影響している可能性があると述べている ${ }^{13)}$. 今回の 結果より脱血不良は治療時に行う対処に加え, カテー テルの構造によるところも大きく，適切な NC カテー テル選択が重要であると考えられる。一方で進藤ら は, カテーテルの脱血不良は内頸静脈と大腿静脈では 差がないと報告しており，留置部位で差がみられな かったのは日常生活活動度 (activities of daily living: ADL) などの影響が大きいと述べている ${ }^{14)}$. 本研究で は，ADL および患者の可動域に関する情報やリハビ リテーション実施状況などは収集しておらず，カテー テルの構造と脱血不良の発生頻度との関連を検討する にあたり，患者の体動が与える影響について考慮する 必要があると考える。

本研究の限界としては, 単施設, 後ろ向きの検討で あったため, 患者背景や NC カテーテルの留置条件な どに偏りがあったこと，さらに維持透析の導入から緊 急 CHDF などさまざまな使用条件で検討を行ったこ となどがあげられる．今後， NC カテーテルの有用性 を評価するには条件を揃えた検討が必要であると考え る.

\section{結＼cjkstart語}

今回，当院では新たに NC カテーテルを導入したの で，脱血不良の発生頻度を後ろ向きに比較した。新し
い NC カテーテルで有意に脱血不良が少なかった．特 に大腿静脈留置時においては有用であることが示唆さ れた。

本研究は第 61 回日本透析医学会学術集会・総会 $(2016$ 年，大阪）で発表した内容にさらに症例集積を行い，検討 を行ったものである.

利益相反：本研究における申告すべきCOI はない.

\section{文献}

1）中島史雄，木村文宏，鈴木智史，他. 大腿静脈カテー テルを用いた血液透析の問題点. 透析会誌 1996；29： 1485-9.

2) Carson RC, Kiaii M, MacRae JM. Urea clearance in dysfunctional catheters is improved by reversing the line position despite increased access recirculation. Am J Kidney Dis 2005； 45：883-90.

3）前田卓馬, 大久保淳, 瀬島啓史, 他. バスキュラーア クセスカテーテル使用時の再循環について. 日血浄化 技会誌 2014；22：160-3.

4）小野淳一, 佐々木慎理, 戸梶めぐみ. Continuous Renal replacement therapy における Blood Access 再 循環の検討. ICU と CCU 2005；29 (別冊)：S161-3.

5）米川元樹, 久木田和丘, 目黒順一, 他. 血液浄化にお ける Double Lumen カテーテルの形状の検討. 薬理と 臨床 1994；4：1405-8.

6) 内田隆行, 安藤勝信, 小藤誠也，他．短期型バスキュ ラーアクセスにおける合併症の比較検討。透析会誌 2011；44: 229-35.

7）久木田和丘, 内田泰至, 増子佳弘, 他. 血液浄化用ブ ラッドアクセスとしてのダブルルーメンカテーテルの 改良と問題点. 人工臓器 $2000 ； 29 ： 478-82$.

8）高橋良光, 塚本功, 三輪泰之, 他. D.L.C を用いた血 液浄化療法施行中に発生するへばりつき現象に関する 検討. ICU と CCU 2008; 32(別冊)：S171-5.

9）武藏健裕. ダブルルーメンカテーテルにおける血管壁 へばりつき現象に関する研究一へばりつき発生因子の 実験的検討一. 透析会誌 2007；40：851-8.

10）佐藤元美, 國松佳奈, 森田裕之. ブラッドアクセスカ テーテルの評価. ICU と CCU 2005；29(別冊)：S1712.

11）慢性血液透析用バスキュラーアクセスの作製および修 復に関するガイドライン。透析会誌 $2011 ； 44 ： 855^{-}$ 937.

12）土屋陽平, 塚本功, 杉村浩, 渡辺裕輔, 鈴木洋通. 当 センターにおける短期型バスキュラーカテーテルの現 状とその性能. 埼玉透析医会誌 2012；1：157-62.

13) Maya ID, Allon M. Outcomes of tunneled femoral hemodialysis catheters: comparison with internal jugular vein catheters. Kidney Int 2005; 68: 2886-9. 
14）進藤充稔, 安藤哲郎, 竹前宏昭, 久保隆史, 添野真嗣. 当院におけるカフ型カテーテルの治療成績一内頸静脈
と大腿静脈の扦入部位による比較一. 腎と透析 別冊 アクセス 2017; 83: 142-4. 